\title{
Familia inguruneko zaintzaileen ongizatea: Sendian Programa
}

\section{Nerea Galdona}

Matia Institutu Gerontologikoa

nerea.galdona@matiafundazioa.eus

\section{Erkuden Aldaz}

Matia Institutu Gerontologikoa

\author{
Aiora Gomez \\ Matia Institutu Gerontologikoa
}

Bizi-itxaropenak gora eta jaiotze-tasak behera egiteak biztanleria zahartu bat izatea dakar, eta, ondorioz, mendekotasunerako arriskuak areagotzea. Familiak, adineko pertsonen zaintzaren euskarri nagusiak, arriskuan jartzen du bere osasun fisikoa eta psikosoziala prozesu horretan. Gipuzkoako Foru Aldundiak behar horiei erantzuten die eta zaintzaile horien ongizatea bermatzen du, Sendian Programaren aldeko apustua eginez. Izan ere, programa horrek banakako babes psikologikoa eta laguntza-taldeak eskaintzen ditu zaintzaileen osasun psikikoa, emozionala eta soziala hobetzeko. Lan honetan, Sendian Programaren erabiltzaileen profila erakusten da eta zaintzaren alderdi positibo batzuk aztertzen dira. Gaur egun, eredu tradizionalari jarraituz, zaintzailearen gehiengoak emakumezkoak dira, nahiz eta gizonezkoen presentzia areagotuz doan. Erabiltzaileek zaintzaren aspektu negatiboak eta positiboak identifikatzen dituzte (azken horien artean, poztasun maila handia eta zainduarekiko gertutasuna, adibidez), baina laginaren $\% 17 \mathrm{k}$ zaintzaren alderdi negatiboak bakarrik jasotzen ditu. Horrek, etorkizunera begira, aurre egin beharreko erronka bat planteatzen digu, eta horri dagokionez, Sendian Programaren prebentzio-balioa nabarmendu dezakegu.

\section{GAKO-HITZAK:}

Mendekotasuna, zaintza, ongizate emozionala, laguntza psikologikoa, Sendian Programa.
El incremento de la esperanza de vida y la baja natalidad conducen a una población envejecida, en la que el riesgo de dependencia aumenta. La familia, principal proveedora del cuidado a personas mayores, compromete su salud física y psicosocial en este proceso. La Diputación Foral de Gipuzkoa atiende estas necesidades y garantiza el bienestar de estos cuidadores apostando por el Programa Sendian, que ofrece apoyo psicológico individual y grupos de apoyo. Este trabajo muestra el perfil de los cuidadores del programa y analiza aspectos positivos del cuidado. Actualmente, las mujeres se encargan mayoritariamente de esta labor, aunque la presencia de los hombres cada vez es mayor. Los cuidadores señalan tanto aspectos negativos como positivos del cuidado (por ejemplo, la satisfacción y la cercanía hacia la persona cuidada). Sin embargo, el $17 \%$ de la muestra solo señala aspectos negativos. Esto supone un reto, respecto al que se podría resaltar el valor preventivo del programa.

\section{Palabras Clave:}

Dependencia, cuidado, bienestar emocional, apoyo psicológico, Programa Sendian. 


\section{Sarrera}

XX. mendeko hirurogeiko hamarkadaren amaieratik hona, ugalkortasun-tasa nabarmenki murriztu da, eta horren ondorioz, adineko pertsonen kopurua gehitu egin da. Biztanleen Udal Erroldaren azken datuen arabera, 2.199.088 pertsona daude Euskadin (INE, 2018). Biztanle horien $\% 20,3 \mathrm{k} 65$ urte baino gehiago dituzte; alegia, 486.738 pertsonak. Horietatik, \% 42,44 gizonak dira eta \% 57,55 emakumeak (Eustat, 2019). Bilakaera demografikoaren beste ondorioen artean, bizi itxaropena luzatzea eta bizi kalitatearen hobetzea aurkitzen ditugu.

Nahiz eta hasera batean osasun arazoek eta mendekotasun egoerek gure bizi kalitatean eragin dezakete zeinahi adinetan, halabeharrez urteetan aurrera joan ahala mendeko izateko aukera areagotuz doa nabarmenki. Mendekotasun egoeran dauden pertsonen artean (36.157 pertsona), adinekoen pisua are handiagoa da \% 76,56k 65 urte baino gehiago baitu. Mendekotasun tasak handiagoak dira adinak gora egin ahala, eta 80 urtetik aurrerakoen tartean are handiagoak. Zehazki, mendekotasuna duten 65 eta 79 urte bitarteko pertsonen artean, \% 20 pisua du; 8otik gorakoen artean, berriz, ehuneko horiek gora egiten dute, adin tarte horren \% 56,47 hartzeraino (INE, 2017).

Familiek mendekotasun egoeran dauden adineko pertsonen eguneroko babes gehiena eskaini izan ohi dute. Zaintza prozesuaren konplexutasunak eta jatorri dinamikoak, eta bestalde, aurrera eraman beharreko zeregin guztien aniztasunak, benetako erronka dakar zaintzaileentzat. Horregatik, zenbait egilek zaintza prozesua lasterketa batekin alderatu izan du; kasu askotan luzea izan ohi dena eta indarrak xahutzen dituena. Gainera, zaintzailearen ongizate fisikoan eta, psikologikoan ere eragin dezake, baita harreman sozio-familiarrak eta lan harremanak aldatzeraino iritsi dezake. Edozein kasutan ere, zaintzaile izateak bere bizitzan ondorio esanguratsuak izango dituenekin lotu izan da, nahiz zenbaitetan positiboak izan (familiarteko bati laguntzeak dakarren sentimenduagatik edo hazkunde pertsonalarengatik).

Horretaz gain, zaintzaileek zaintza lanarekin erlazionatuta zeregin ugari dituzte bere egunerokotasunean, eta egiteko hauek denboran zehar asko luzatzen dira. Aitzitik, zaintzaile guztiak oso antzeko egoeren aurrean aurkitzen badira ere, ez dituzte guztiek ondorio berberak jasaten, edo ez behintzat intentsitate berdinarekin. Egoera hau zein den kontutan harturik, Gipuzkoako Foru Aldundia zaintzaileen ongizatea eta euren beharrak asetzera zuzenduta dauden programa anitz garatzen ari dira: eta testuinguru honetan kokatzen da artikulu honen bidez deskribatu nahi dugun Sendian Programa.

\section{Biztanleriaren zahartzea Euskal Autonomia Erkidegoan}

Euskal Autonomia Erkidegoan (EAE) 2.188.017 pertsona daude, eta horietatik 486.738 lagunek 65 urte baino gehiago dute dagoeneko. Hauek, biztanleria osoaren \% 22,25 da; hots, biztanleriaren 3 pertsonatatik 2 adinekoak dira EAEn. Bestalde, 16-34 bitarteko gazteek \% 18,36ko pisua dute (Eustat, 2019).

2026. urtera begira egindako biztanleria proiekzioen arabera, 65 urte eta gehiagoko pertsonen proportzioa $\% 30$ ingurukoa izatea aurreikusten da. Ordurako

1. taula. Adin eta sexuaren araberako biztanleria. EAE, 2019.

\begin{tabular}{|l|c|c|c|c|c|c|}
\cline { 2 - 7 } \multicolumn{1}{c|}{} & \multicolumn{2}{c|}{ Bi sexuak } & \multicolumn{2}{c|}{ Gizonezkoak } & \multicolumn{2}{c|}{ Emakumezkoak } \\
\cline { 2 - 7 } \multicolumn{1}{c|}{} & Guztira & $\%$ & Guztira & $\%$ & Guztira & $\%$ \\
\hline 0-19 urte & 401.766 & 18,36 & 206.528 & 19,45 & 195.238 & 17,33 \\
\hline $20-64$ urte & 1.299 .513 & 59,39 & 648.463 & 61,08 & 651.050 & 57,80 \\
\hline 65 urte eta gehiago & 486.758 & 22,25 & 206.606 & 19,46 & 280.132 & 24,87 \\
\hline Guztira & 2.188 .017 & 100,00 & 1.061 .597 & 100,00 & 1.061 .597 & 100,00 \\
\hline
\end{tabular}

Iturria: Matia Institutu Gerontologikoa, Eustatetik ateratako datuekin.

2. taula. Biztanleria proiekzioak, adin eta sexuaren arabera. EAE, 2026.

\begin{tabular}{|l|c|c|c|c|c|c|}
\cline { 2 - 6 } \multicolumn{1}{c|}{} & \multicolumn{2}{c|}{ Bi sexuak } & \multicolumn{2}{c|}{ Gizonezkoak } & Emakumezkoak \\
\cline { 2 - 6 } & Guztira & $\%$ & Guztira & 176.561 & 18,0 & 171.378 \\
\hline $16-34$ urte & 347.939 & 17,1 & 426.093 & 43,4 & 435.578 & 41,2 \\
\hline $35-59$ urte & 861.671 & 42,2 & 236.129 & 24,1 & 314.462 & 29,7 \\
\hline 65 urte eta gehiago & 550.591 & 27,0 & 981.767 & 100,0 & 1.057 .722 & 100,0 \\
\hline Guztira & 2.039 .490 & 100,0 & & & \\
\hline
\end{tabular}

Iturria: Matia Institutu Gerontologikoa, Eustatetik ateratako datuekin. 
550.591 pertsona inguru izango dira eta zifra hau 16-34 urte bitarteko biztanleria gaztearen portzentaia baino altuagoa izango da zinez.

1. irudiak EAEko demografiaren etorkizuna nabarmentzen du. 2026 urterako, biztanleria gehiena metatzen duten kohorteak 50 urtetik gorakoak dira. Aitzitik, 25 eta 45 urte bitarteko biztanleen artean jaitsiera nabarmena aurreikusten da. Bestalde, modu esanguratsuan gora egingo duen beste adintarte bat ehun urtetik gorako pertsonena da; izan ere, 2026 urterako, EAEn, 100 urtetik gorako 2.000 pertsona inguru egotea aurreikusten baita, gehienak emakumeak izaki. Adin horretako emakumeak, zehazki esanda, gizonezkoen halako 4 izango dira.

Baina egoera demografiko hau ezberdina da lurralde, eskualde eta herri bakoitzean. Zenbait ikerketen arabera, Bizkaia da 65 urtetik gorako pertsona gehien dituen lurraldea (\% 22,7), eta jarraian Gipuzkoa (\% 22,2) eta Araba (\% 20,7). Guztien arteko aldeak ez dira oso nabarmenak; guztietan ere \% 2 ko diferentzia baino ez da antzematen.

Datu zehatzak aztertzen jarrita, badirudi, ordea, Araba (Arabako Mendiak, \% 26,7) dela herrialde zaharkituena eta ia 9,8 puntu portzentualeko aldea du lurralderik gazteenarekin (Plentzia-Mungia, $\%$ 16,9). Zahartze-tasarik altuena erakusten duten eskualdeak, EAEn, Arabako Mendiak (\% 26,7), Markina-Ondarroa (\% 23,6), Debagoiena (\% 23,4) eta Bilbo Handia $(\% 23,4)$ dira. Eta bestalde, adineko pertsonen ehuneko baxuena duten herrialderik gazteenak Plentzia-Mungia (\% 15,2), Kantauri Arabarra $(\% 18,5)$ eta Urola Kosta $(\% 19,5)$ dira.

EAEko 251 herritatik 107tan, adineko pertsonen biztanleria \% 20 baino altuagoa da. Hau da, 10 herritatik 4 etan, adineko pertsonen ehuneko $\%$ 2otik gorakoa da. Bestalde, 21 herrik \% 25etik gorako proportzioa erakusten dute, eta hauetan, lau pertsonatatik batek dagoeneko 64 urte baino gehiago ditu. Zerrenda honetan ageri diren hedadura handiko lehen herrien artean, Portugalete eta Basauri aipatu daitezke. Zifrarik altuena duen lehen hiria Bilbo da $(\% 23,2)$, Donostia ondoren $(\% 22,2)$ eta jarraian, Gasteiz $(\% 19,1)$.

Gipuzkoan, Urola Kosta da 85 urte edo gehiagoko biztanleria baxuena erakusten duen eskualdea (\% 2,9), eta ondoren, Tolosaldea (\% 3,2). Aitzitik, Tolosaldea, Bidasoa, Goierri, Donostialdea eta Debagoiena \% 3,2tik gorako proportzioa erakusten dituzte, \% 4,3ko proportzioak Debabarrenak duelarik. 85 urtetik gorako pertsona gehien dituzten herriak Leaburu $(\% 5,3)$, Ezkio-Itsaso eta Olabarria $(\% 4,9)$ eta Eibar $(\% 4,8)$ dira. Donostian, berriz, \% 4,2a da portzentaje hau (Behagi, 2018).

1. irudia. EAEko biztanleria piramidea. 1996, 2014 eta 2029

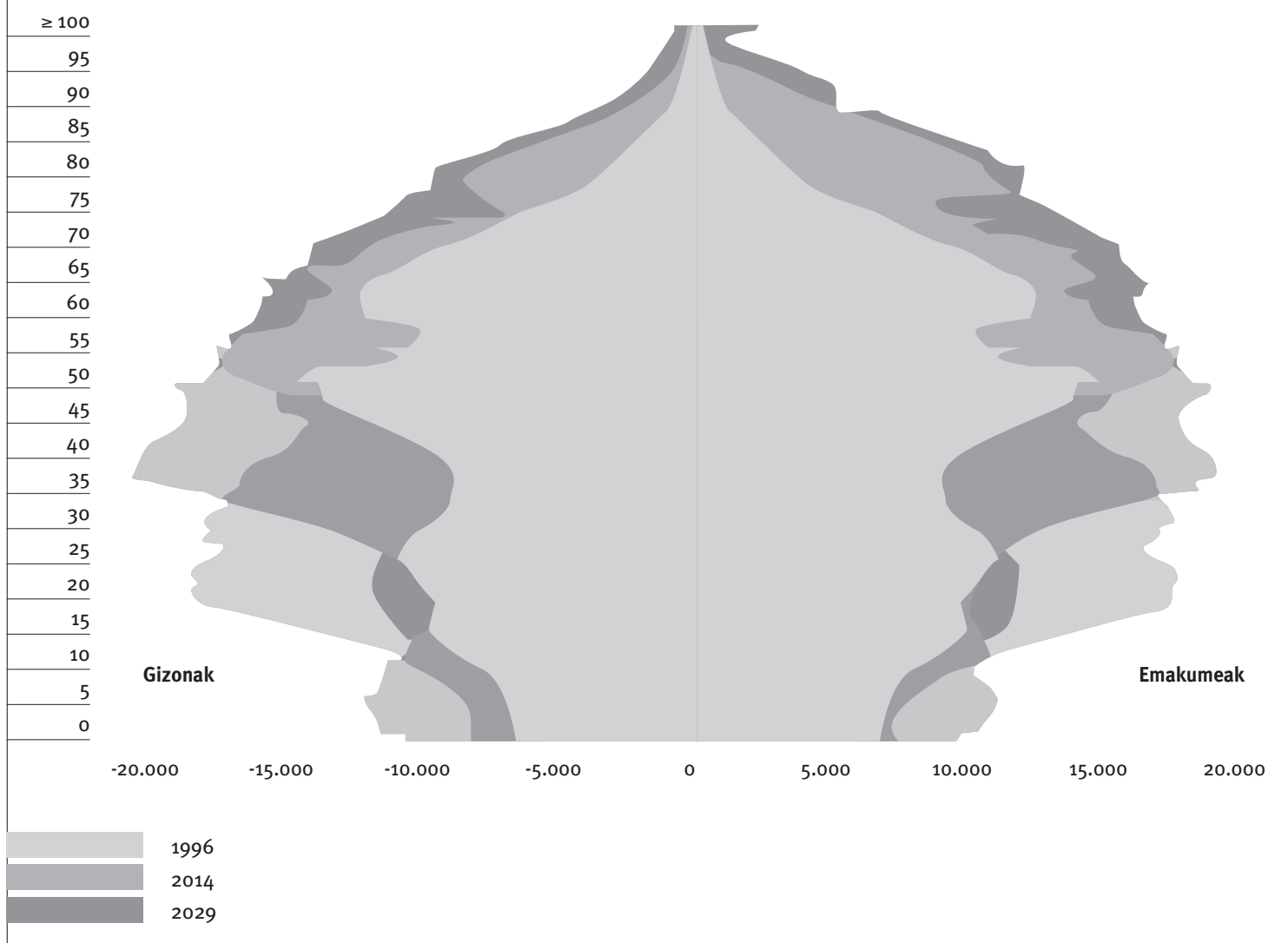

Iturria: Matia Institutu Gerontologikoa, Eustatetik ateratako datuekin. 


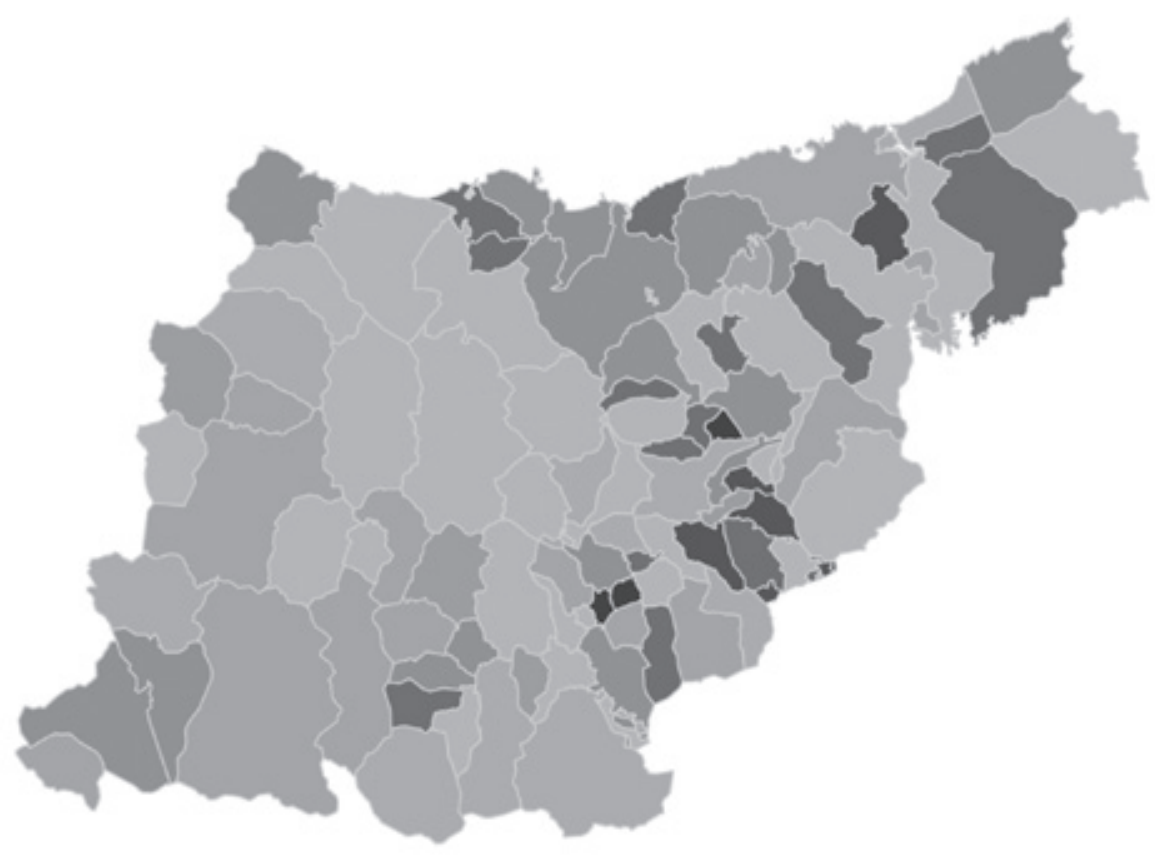

Eskala

0,7 5,3

Iturria: Matia Institutu Gerontologikoa, Behagitik ateratako datuekin.

Mendekotasun baremoa erabilita baloratu diren pertsonen proportzioa (I-III mailak) \% 3,75koa da Donostian, hau da, ia 100 pertsonatatik 4eri mendekotasunaren balorazioa egin zaio. Goierri litzateke, bestalde, balorazio gehien eginak dituen eskualdea $(\% 4,64)$ eta Bidasoa, berriz, baxuena duena $(\%$ 3,21). Donostiako kasura itzuliz, $65-79$ urte bitarteko 1.105 pertsonari egin zaio balorazioa, eta 80 urtetik gorako beste 4.115 pertsonari (Behagi, 2018).

Matia Institutu Gerontologikoak, Eusko Jaurlaritzako Enplegu eta Gizarte Politiketarako Sailarekin elkarlanean argitara emandako EAEko 55 urte eta gehiagoko pertsonen bizi-baldintzen ikerketak garbi uzten du, laguntza beharra duten pertsonen kasuan, etxean bizitzen jarraitzeko lehentasuna nabaria dela; izan ere, etxean geratu nahi luketen pertsona horiek ia \% 84 dira. Adina aurrera doan heinean, etxean bizitzen jarraitzeko desioa ere gero eta nabariagoa da, eta aipatutako ikerketak adierazten duenez, 80 urtetik gorako pertsonen artean, ia \% goko pisua hartzen du (Barrio, Mayoral eta Sancho, 2015).

\section{Familiartean zaintzak}

Menpekotasun egoeran dauden adineko pertsonen zaintza familiarra garrantzia bereziko gizarte-erronka da, eta goranzko noranzkoan darraien arazo bilakatu da; familiak gero eta erantzukizun handiagoa izan ohi du eguneroko zaintza burutzeko, eta gainera epealdi luzeetan zehar hedatzen da. Gurean ez dugu halako beste aurrekaririk (bizi-itxaropena luzatzea, jaiotzatasen jaitsiera, biztanleria zaharkitua). Egoera hau gero eta ohikoagoa da, bada, zaintzaile nagusien eta hauen familiako beste kideen artean, eta kontuan hartzekoa da, alafede, hauengan duen eragin fisiko eta psikologikoa ere.

Familia gehienetan, pertsona bakarra izan ohi da zaintza lanak beregain hartzen dituena: zaintzaile nagusia. Gehienak emakumezkoak izan ohi dira; gero eta gizonezko gehiagok badihardute ere (zaintzaile nagusien laguntzaile gisara, soilik). Zaintzailearen eta zaindutako pertsonaren ahaidetasunari dagokionez, ezkontidea zaintzen duen zaintzailearen profila da ugariena. Ondoren, garrantziari dagokionez, bigarren taldea seme-alabak osatuko lukete. Zaintzaileen zeregin eta jarduerak oso ezberdinak izan ohi dira, denbora eta energia handia eskatzen dute, eta ez dira eroso eta atseginak izaten maiz. Horrez gain, zainketa jarduera hauek ez dira aurreikusten eta honen ondorioz, ez da sarri askotan zaintzailea egoera berri horretarako prest egoten; ez eta, zaintza prozesuan aurre egin beharko dion egoera aniztasunerako ere. Hau eta beste zenbait arrazoirengatik, zaintza esperientzia bakarra eta gainontzekoetatik ezberdina izan ohi da. Aipatu bezala, zaintzaileek zaintza lanarekin erlazionatutako eta eskaera gero eta handiagoa duten zeregin ugari egiten dituzte. Zaintzaren intentsitateari dagokionez, Espainia 
mailan 820 zaintzaileekin egindako ikerketan batean aurkitu zuten batez beste, ehuneko \% 62ak zaintzera bideratzen den denbora egunean 6 eta 12 ordu tartekoa dela (Artaza eta Ramos Cordero, 2016).

Nahiz eta familien rola zaintza lanetan geroz eta gehiago aintzat hartzen den, 1980 hamarkadara arte ez zuten aztertu zaintzak zaintzailearen ongizatean izan dezakeen eragina. Zaintzaileekin egin izan diren lan gehienek, abiapuntu bezala Pearlin eta beste batzuen estres prozesuaren eredua da (Pearlin et al., 1990). Labur esanda, estresaren ereduak zaintzaile ezberdinen arteko aldea hobeto ulertzen laguntzen du; alegia, zaintza lanari aurre egiteko duten moduan eta honek euren osasunean dituen ondorioak alderatzeko balio du. Eredu honetan proposatzen da elkarrekin lotura duten aldagai batzuk daudela: zaintzailearen aurreko garaia edo egungo testuingurua (zaintzailearen adina edo ikasketa maila, adibidez), lehen mailako faktore estresagarriak (alde batetik mendetasuna duen pertsonaren narriaduratik eratortzen direnak eta bestetik zaintzaileak ematen duen arretak eragindakoak), bigarren mailako faktore estresagarriak (rolaren faktore estresagarriak eta faktore estresagarri intrapsikikoak), emaitzak/ ondorioak eta bitartekariak (faktore estresagarrien eta ondorioen gainean eragiten dute, adibidez, harreman sozialek).

Orain arte egindako ikerketa gehienek mendekotasun egoeran dagoen adineko pertsona baten zaintzak dituen ondorio negatiboetan jarri dute arreta, nahiz eta zaintzeak ondorio positiboak ere izan ditzakeen. Zaintzak zaintzailearen egoera psikologiko, ekonomiko, sozialean eta fisikoan (Kuzuya, Enoki eta Hasegawa, 2011; Casado eta Sacco, 2012 ) eragina izan dezake. Laburbilduz ondorio negatibo horiek hiru dimentsio nagusitan taldekatu daitezke:

a. Dimentsio fisikoa: zaintza prozesuak zaintzaileen sistema inmunologikoan, arazo osteomuskularretan, lo arazoetan edo gaixotasun kardiobaskularren garapenean eragin dezake (Nardi et al., 2012).

b. Dimentsio psikologiko-emozionala: zaintzaileen artean, sarrien aurkitu izan diren ondorioak depresio eta antsietate sintomak, autonomia edo askatasun galera, kulpa eta frustrazioa sentimenduak izan dira, besteak beste (Rogero, 2010; Knight eta Losada, 2011; Pinquart eta Sorensen, 2003). Zaintzaileak ez diren pertsonak baino osasun mental, emozional eta fisiko okerragoa dutela aztertu izan da (Nardi et al., 2012).

c. Gizarte dimentsioa: zaintzak zaintzaileen harreman sozialetan duten eragina esanguratsua da: gizarte-isolamendua, aisialdirako ekintzetarako edo deskantsurako denbora nabarmen murriz daiteke (Bocci et al., 2010; Gonçalves et al., 2011).

Nahiz eta ikerketa gehienak zaintzaren alderdi negatiboak aztertu dituzten, mendekotasuna duen pertsona baten zaintzak eragin positiboak ere izan ditzake, hala nola, hazkunde pertsonala, balioen transmisioa, erantzukizunaren zentzua eta maitasun sentimendua (Chan, 2010; De Oliveira eta Caldana, 2012). Zaintza lanek dakartzaten onurak aztertzen dituzten egileek diotenez, sentimendu positiboak erakusten dituzten zaintzaileek depresio gutxiago, gainkarga arinagoa eta bere osasunaren balorazio positiboagoa egiten dute (Hilgeman et al., 2007).

\section{Zaintza, guztion erantzukizuna}

Gure lurraldeari erantzuna emanaz, Gipuzkoako Foru Aldundiak berdintasunerako foru plan bat burutu zuen (II. Emakume eta Gizonen arteko Berdintasunerako Foru Plana), eta bertan zaintza lanak unibertsalitate eta singularitate perspektiba batetik lantzen dira. Horretarako, plan honek egiteke dagoen horretan guztian aldaketak proposatzen ditu, eta hau abiapuntu izanda, zaintzarako eskubidea edonori bermatuko zaintzen eredu eta antolaketa bat sustatu nahi du, bizitzaren zainketa lanak guztion ardura direla azpimarratuz.

Krisi testuinguru honetan, zaintza lanen gaia hurrengo galderak mahai gainean jarrita eztabaidatzea proposatzen da. Zer neurritan okertuko da zaintza-lanen krisia zerbitzu publikoak kendu eta zainketa hauek etxera pasatzen doazen neurrian? Gero eta zailagoa den lan-munduratzeak zenbateraino ekarriko du emakumeak etxera itzultzea? Zein neurritan osasunaren narriadura etengabeak (osasun baldintza txarragoak eta osasun-zerbitzurako sarbidea zailagoa delako) gainkargatuko ditu etxebizitzak, eta bereziki emakumeak? Orokortua dagoen krisi egoera honetan, arrisku handia dago familia tradizionala deritzona sendotzeko, eta honekin batera, bere baitan ematen diren genero errolak berfinkatzeko.

Interdependentzia errealitate mota bat da zaintza lanena, eta ezin dira pertsona autonomo liratekenetatik mendekotasuna luketengana aldebakarrez egiten diren jarduera bezala ulertu. Zaintzak ikuspegi zabal eta mugagabe batetik ulertu behar dira. Pertsona guztiek, bizitzako momentu guztietan behar dituzte zaintzak, nahiz hauek izaera eta intentsitate berbera ez izan.

\section{Zaintza duinak eta unibertsalak}

Aipatutako planean, duintasunaz hitz egiten da, eskainitako eta jasotako zaintzak nahikoak izango direla kopuruan (egungo eskaera aseko dutenak), eta kalitatekoak izango direla, alegia, modu askean aukeratuak (norberak nola zaintzea izan nahi duen aukeratzeko askatasuna eduki dezala). Halere,

egungo zaintzen ereduan, eta Gipuzkoako testuinguruan, zirkulu bizioso bat sortzen da. Zaintza lanek desberdintasunaren bektore sortzen ditu, alegia, zaintza duin edo prekario baterako sarbidea 
diferentziazio sozialerako oinarrizko elementua da, eta aldi berean, honek desberdintasunak areagotzen ditu.

Unibertsalitate irizpidearen arabera, zaintza duinak pertsona guztientzat izan behar dira, eta ez gutxi batzuentzat soilik. Alegia, zainketa duin batzuetarako sarbidea ezin daiteke beste zainketa prekario batzuen kontura izan. Bestalde, singularitateaz ari garenean, egoera sozial bakoitzaren diferentziak errespetatzeaz ari gara.

Gurea, ordea, oso testuinguru ezberdinean kokatzen da. Gipuzkoan egoera oso ezberdinak daude eta hauei eman beharreko erantzuna ere anitza izan behar da. Ezin daiteke zainketak nola burutu erabakitzerakoan aukera bakarra hautatu.

Gipuzkoako Foru Aldundiak zaintza-lanen egungo antolaketa ez dela justua iritzi dio: sistema sozioekonomikoaren ezkutuko oinarri dira zaintzalanak, eta hauek ematerakoan ez dago erantzukizun kolektiborik. Erantzukizun hau etxebizitzatan eta emakumeen eskutan pribatizatua dago; eta bere oinarrian, ordaindu gabeko lana eta etxeko lana aurkitzen dira.

Ezinbestean, ordea, Gipuzkoako zaintza kultura ezberdinei begiratu behar zaie, eta ongi zaintzea nola definitzen duten, nork nor zaintzen duen, non eta zeren truke egiten duten aztertu behar da. Gaur egun, zainketa lanen etika idealizatu eta sustatzen duten proposamenek, emakumeek familiaren ongizatearekiko duten erantzukizun sentsazioa lehertzen dute, eta beraz, ez dira zaintza horiek emakumeen testuingurutik haratago burutzeko lehen premisak zehazten.

Etxebizitzek erronka eta testuinguru berri bati aurre egin behar diete. Gisa batera edo bestera, adineko pertsona, adingabeko eta aniztasun funtzionalen bat duten pertsonen beharrizanak Gipuzkoan, EAEn eta Estatu mailan izaera mugagabea duten estrategien arabera asetzen dira (lan-merkatuan lan egiteari uztea); eta aldi baterakoak (eszedentziak), espazialak (zaindutako pertsonengandik hurbilago bizitzea), zeharkakoak (esaterako, amatasuna atzeratzea). Guztiak ere ez dira, inolaz ere, beti zaintzaileen eta zaindutako pertsonen ongizaterako aukera egokienak izango. Kasu guztietan, familia izango da gehien erabiliko den babes sarea. Areago, adineko pertsona eta aniztasun funtzionalen bat duten pertsonen kasuan, zainketa lanen antolaketa konplexuagoa da. Kasu askotan, zereginen banaketa oso maiz ez da behar bezala burutzen, eta zainketa-lanen pisu handiena, beste behin ere, emakumeen gain jartzen da.

Aurrekoak esanda, Gipuzkoako Foru Aldundiak zaintzaileen ongizatea bultzatuko duen, eta euren beharrizanak hobeto asetuko dituzten proposamenak jarrai nahi ditu mahai gainean,: eta testuinguru honetan kokatzen da, artikulu honetan aurkeztu nahi dugun Sendian Programa. Programa hau 29/2008 Foru Dekretuan onetsi zen eta bere aplikazio eremua Gipuzkoako lurralde historikoaren eremu geografikoan kokatzen da. Mendekotasun egoeran dauden adinekoen familia zaintzaileei zuzenduta dago eta, oro har, programa honen helburuak honako hauek dira:

- Mendekotasun egoeran dauden pertsonei familiartekoek ematen dieten zainketaren kalitatea hobetzea.

- Zaintzaileen bizi kalitatea hobetzea.

- Mendekotasun egoeran dagoena ahalik eta denbora gehienean eta ahalik eta baldintza onenetan etxean eta bere ohiko ingurunean mantentzen laguntzea.

- Emakume zaintzaileen jabekuntza bultzatzea eta zaintza lanen ardura emakumeen eta gizonen artean banatzea sustatzea.

3. taulan estaldura tasak eta eskualde bakoitzean jasotako pertsona erabiltzaileak jasotzen dira (Behagi, 2018). Ikusten den bezala, estaldura tasarik handiena Urola Kostan ematen da \% 1,99rekin, Bidasoako \% 0,92ren aldean.

3. taula. Sendian Programaren estaldura tasak, eskualdeka. 2018.

\begin{tabular}{|c|c|c|c|c|c|c|c|}
\hline & Bidasoa & Debabarrena & Debagoiena & Donostialdea & Goierri & Tolosaldea & Urola Kosta \\
\hline $\begin{array}{l}\text { Sendian Programaren estaldura, guztira } \\
\text { (1.000 biztanleko) }\end{array}$ & 0,92 & 1,29 & 1,46 & 1,13 & 1,91 & 1,25 & 1,99 \\
\hline $\begin{array}{l}\text { Sendian Programaren estaldura } 65 \\
\text { urte eta gehiagoko biztanlerian ( } 1.000 \\
\text { biztanleko) }\end{array}$ & 0,42 & 0,53 & 0,62 & 0,48 & 0,83 & 0,58 & 0,96 \\
\hline $\begin{array}{l}\text { Sendian Programan alta emanda } \\
\text { dagoen pertsona kopurua, abenduaren } \\
\text { 31n }\end{array}$ & 73 & 72 & 91 & 374 & 133 & 60 & 151 \\
\hline $\begin{array}{l}\text { Sendian Programan alta emanda } \\
\text { dauden } 65 \text { urte eta gehiagoko } \\
\text { pertsonak }\end{array}$ & 72 & 68 & 89 & 361 & 124 & 56 & 140 \\
\hline Biztanleria osoa & 79.001 & 55.703 & 62.527 & 330.169 & 69.561 & 47.880 & 75.751 \\
\hline 65 urte eta gehiagoko biztanleria & 16.967 & 12.882 & 14.452 & 74.596 & 14.912 & 9.701 & 14.545 \\
\hline
\end{tabular}

Iturria: Matia Institutu Gerontologikoa, Behagitik ateratako datuekin. 
4. taula. Sendian Programaren estaldura tasak, urteka. 2008-2018

\begin{tabular}{|c|c|c|c|c|c|c|c|c|c|c|c|}
\hline & 2008 & 2009 & 2010 & 2011 & 2012 & 2013 & 2014 & 2015 & 2016 & 2017 & 2018 \\
\hline $\begin{array}{l}\text { Sendian } \\
\text { Programaren } \\
\text { estaldura, } \\
\text { guztira (1.0oo } \\
\text { biztanleko) }\end{array}$ & 1,69 & 1,94 & 1,62 & 1,87 & 1,97 & 2,05 & 2,52 & 1,90 & 1,72 & 1,94 & 1,32 \\
\hline $\begin{array}{l}\text { Sendian } \\
\text { Programaren } \\
\text { estaldura } \\
65 \text { urte eta } \\
\text { gehiagoko } \\
\text { biztanlerian } \\
(1.000 \\
\text { biztanleko) }\end{array}$ & 0,89 & 1,01 & 0,82 & 0,92 & 0,95 & 0,98 & 1,17 & 0,87 & 0,77 & 0,88 & 0,58 \\
\hline $\begin{array}{l}\text { Sendian } \\
\text { Programan } \\
\text { alta emanda } \\
\text { dagoen } \\
\text { pertsona } \\
\text { kopurua, } \\
\text { abenduaren } \\
\text { 31n }\end{array}$ & 1.188 & 1.371 & 1.148 & 1.327 & 1.403 & 1.462 & 1.799 & 1.365 & 1.233 & 1.395 & 954 \\
\hline $\begin{array}{l}\text { Sendian } \\
\text { Programan } \\
\text { alta emanda } \\
\text { dauden } 65 \\
\text { urte eta } \\
\text { gehiagoko } \\
\text { pertsonak }\end{array}$ & 1.153 & 1.329 & 1.103 & 1.270 & 1.342 & 1.409 & 1.729 & 1.315 & 1.184 & 1.342 & 910 \\
\hline $\begin{array}{l}\text { Biztanleria } \\
\text { osoa }\end{array}$ & 701.056 & 705.698 & 707.263 & 709.607 & 712.097 & 713.818 & 715.148 & 716.834 & 717.832 & 719.282 & 720.592 \\
\hline $\begin{array}{l}65 \text { urte eta } \\
\text { gehiagoko } \\
\text { biztanleria }\end{array}$ & 128.911 & 131.611 & 134.320 & 137.865 & 140.874 & 143.872 & 147.570 & 150.591 & 152.979 & 152.979 & 158.055 \\
\hline
\end{tabular}

Gaur egun, Sendian Programan banakako babes psikologikoa eta laguntza taldeak eskaintzen dira. Ondorengo ataletan, zerbitzu bakoitzaren ezaugarri nagusienak eta datuak aurkezten dira.

\section{Sendian Programa: banakako babes psikologikoa}

Bakarkako laguntza psikologikoek zaintzaileen osasun psikologiko, emozionala eta soziala hobetzeko neurri terapeutikoak eskaintzea dute helburu nagusitzat. Banakako babes psikologikorako saioen eragin-esparrua, bereziki, zaintzaileen osasun psikiko, emozional eta soziala zaintzeko babes terapeutikoa eskaintzean oinarritzen da. Saio hauen edukiak oso aldagarriak dira eta etengabe egokitzen dira zaintzaile bakoitzaren egoera propiora.

Eredu sistemiko-kognitibo-narratibo batetik, menpekotasuna duen adineko pertsona baten kargura egoteak sortzen dituen ondorio psikoafektibo eta erlazionalak lantzen dira, besteakbeste; rolen aldaketa, depresioa, antsietatea, “jada ez da lehengoa”, bakartasun sentimendua, erabakiak hartzean, ingurunearekiko harremana, norbere burua zaintzen ikastea. Eta hau guztia honako hauek lortzeko:
- Zaintzailearen ahalduntze edo gaitzea sustatu.

- Familiartekoek euren emozioak bideratu eta espresatu ditzaten babes emozionala eskaini.

- Menpekotasunari familiartean aurre egiten lagundu.

- Kaltegarriak diren erreakzio emozionalak saihestu, eta ahal den neurrian menpekotasuna duen pertsonarekiko erantzunak bilatzen lagundu.

- Egokiak ez diren edo bideratu gabeko zenbait jarrera zuzentzea.

Kasu gehienetan, banakako babes psikologikorako terapietan, lehenengo hiru saioak laguntza jasoko duen zaintzailearen egoera emozionala baloratzeko erabiltzen dira; hurrengo seiak, balorazio garaian finkatutako helburuak lantzeko; eta hiru saio luzagarrik, laguntza ongi jaso dutenak, eta aurrez finkatutako helburuak behar beste landu ezin izan diren kasuetarako: bataz-bestez, hamar saioko terapiak osatuz pertsona bakoitzeko. 2018. urtean 941 babes indibidualeko saio burutu dira, eta guztira 210 kasu artatu. Azken urteotan hazkunde esanguratsu bat egon da artatutako kasu kopuruan, 5. taulan zehazki ikus dezakegu 2007 urtetik 2018 urtera banakako kasuen kopuruen garapena. 
5. taula. Artatutako banakako babes psikologikoko kasuak, urteka. 2007-2018

\begin{tabular}{|c|c|}
\hline Urtea & Artatutako kasu kopurua \\
\hline 2007 & 16 \\
\hline 2008 & 116 \\
\hline 2009 & 115 \\
\hline 2010 & 86 \\
\hline 2011 & 95 \\
\hline 2012 & 100 \\
\hline 2013 & 100 \\
\hline 2014 & 88 \\
\hline 2015 & 100 \\
\hline 2016 & 88 \\
\hline 2017 & 119 \\
\hline 2018 & 210 \\
\hline
\end{tabular}

Iturria: Matia Institutu Gerontologikoa.

2018 urtean banakako laguntza psikologikoa oinarri duen zerbitzutik hartutako datuetatik \% 89 emakumezkoak dira. Laginaren erdiak baino gehiago (\% 63) bere aita edota ama zaintzen du, \%33 ezkontidea zaintzen duen bitartean. Kasu honetan, galdesorta bete duten pertsonen bataz besteko adina 59 urtekoa da, baina adin tartea oso zabala da 37-79 urte bitartekoa. Aita edo ama zaintzen duten zaintzailearen profila honako ondokoa da: alabarena eta bataz besteko adina 53 urtekoa. Ezkontidea zaintzen duen zaintzaileen kasuan, emakume zaintzailearena eta bataz besteko adina 71 urtekoa eta bataz beste 6 urte daramatza zaintzen.

3. Irudia. Laginaren banaketa egoera zibilaren arabera (\%)

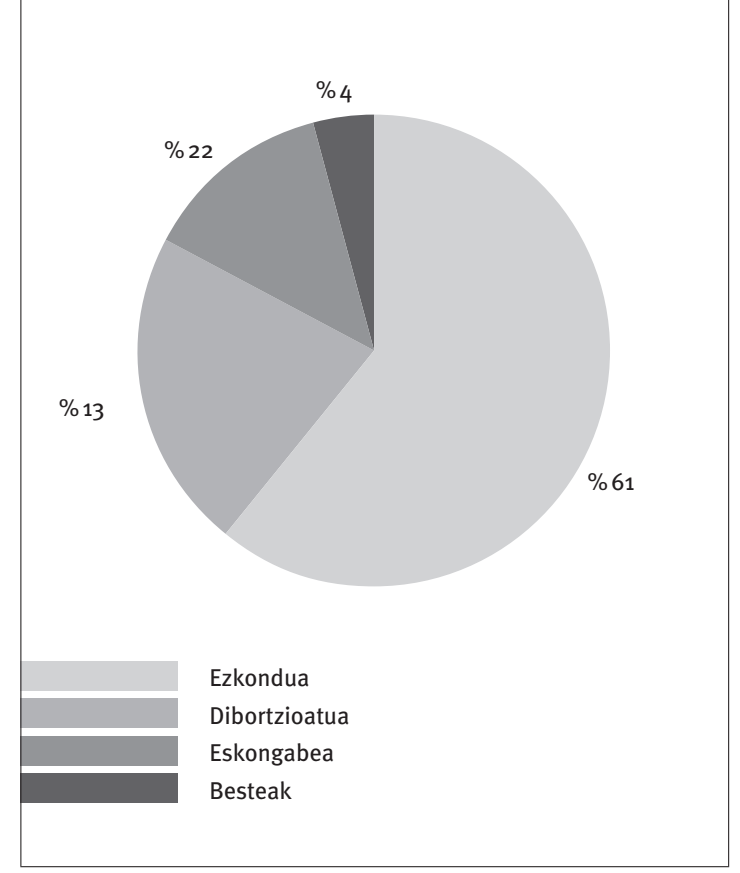

Iturria: Matia Institutu Gerontologikoa.
Zaintzen daraman denborari dagokionez, egia da 6,43 urte daramatzatela bataz beste zaintzen baino aldakortasun handia dago zaintzaile batzuen eta besteen artean (urte bete eta 30 urte artean). Elkarbizitzari dagokionez, zaintzen duten gehienak, $\% 74$ alegia, zaindutako pertsonarekin bizi dira.

Galdesorta erantzun dutenen artetik, senitartekoak zaintzen dituzten gehienak ezkonduak dira (\% 61); hala ere, zaintzaile ezkongabeen (\% 22) eta bananduen (\% 13) multzoa ere ez da txikia. 3. irudian ikus dezakegu zaintzaileen laginaren banaketa egoera zibilaren arabera.

Gizartean oro har izan diren aldaketei jarraituz, ikasketarik gabe zaintzailerik ia ez dagoela esan dezakegu (\% 2). Lehen mailako ikasketak dituzten zaintzaileak dira galdesorta egin duten gehienak (\% 44), lanbide ikasketak (\% 24) dituztenak jarraituz. 4. irudian ikus dezakegu laginaren banaketa ikasketa mailaren arabera.

Ebaluatu diren zaintzaileetatik, erdiak baino pixka bat gutxiago (\% 48) dementzia duen pertsona bat zaintzen du. Minbizia duten pertsona edo iktusen bat pairatu dutenen pertsonen kasuak ere geroz eta maizago agertzen dira. Bestaldetik,

zaintza aurrera eraman ahal izateko \% 7oak laguntzaren bat jasotzen duela aitortzen du eta zehazki gehienak diru-laguntza bat jasotzen du zaintza aurrera eraman ahal izateko, hau da, laguntza pertsonalerako prestazio ekonomikoa eta familia ingurunean zaintzetarako profesionalak ez diren zaintzaileei laguntzeko prestazio ekonomikoa.
4. Irudia. Zaintzaileen banaketa ikasketa mailaren arabera (\%)

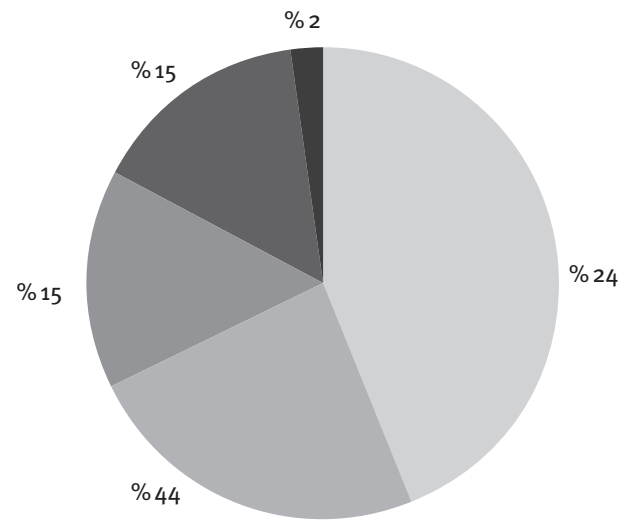

Irakurketa eta idazketa oinarrizko maila Batxilergoa

Lehen mailako ikasketak Bigarren mailako ikasketak Goi mailako ikasketak 


\section{Sendian Programa: laguntza taldeak}

Laguntza talde hauetan erabiltzen den ikuspegiak ere Pertsona Oinarri duen Arreta Eredua hartzen du abiapuntu. Beste esparru eta kolektibo ezberdinekin arrakasta handia izan duen eredu honi esker, "hainbat balio eta estrategia pertsona bakoitzari bere etorkizuneko irudia osatzeko eta helburu honetarako zehaztu beharreko plana osatzeko ahalegin berezia egiten da".

\section{Arreta eredu honek:}

- Zaintza lanean diharduten pertsonei indarra ematen die, beren bizitzaren eta erabakien jabe izaten ikas dezaten.

- Zaintzaileek euren bizitzan zer duten garrantzitsuena entzuteko balio du, eta sentimendu eta ikuspegi ezberdinak azaltzeko balio die.

Laguntza talde bakoitzak 6 eta 20 partaide artean izaten ditu, talde bakoitzean profesional bat egongo da, taldea koordinatu eta zuzendu ahal izateko. Saioen maiztasunari dagokionez, urtean talde bakoitzak bataz beste 20 saio bat egiten da.

2018 urtean 260 zaintzaileek hartu dute parte laguntza taldeetan. 6. taulan, 2007-2018 epealdian izandako laguntza talde eta hauetako partaide kopurua zehazten dira.

6. taula. Laguntza taldeak eta partaide kopurua. 2007-2018

\begin{tabular}{|l|c|c|}
\hline Urtea & Talde kopurua & Partaide kopurua \\
\hline 2007 & 16 & 136 \\
\hline 2008 & 18 & 182 \\
\hline 2009 & 18 & 169 \\
\hline 2010 & 17 & 169 \\
\hline 2011 & 15 & 266 \\
\hline 2012 & 17 & 239 \\
\hline 2013 & 18 & 230 \\
\hline 2014 & 22 & 244 \\
\hline 2015 & 20 & 262 \\
\hline 2016 & 22 & 253 \\
\hline 2017 & 24 & 256 \\
\hline 2018 & 22 & 260 \\
\hline
\end{tabular}

Iturria: Matia Institutu Gerontologikoa.

Laguntza taldeetan parte hartzen duten zaintzaileei galdesorta bat betearazten zaie. Galdesorta bete duten pertsonetatik \% 87 emakumezkoak dira. laginaren erdiak baino pixka bat gehiago bere ezkontidea ( $52 \%$ ) zaintzen du, baina bada talde esanguratsu bat ere bere aita/ama (44\%) zaintzen duena. Senitartekoak zaintzen dituzten gehienak ezkonduak dira (\% 79), hala ere zaintzaile ezkongabeen (\% 15) multzoa ere ez da txikia.

5. Irudia. Zaintzaileen proportzioa egoera zibilaren arabera (\%)

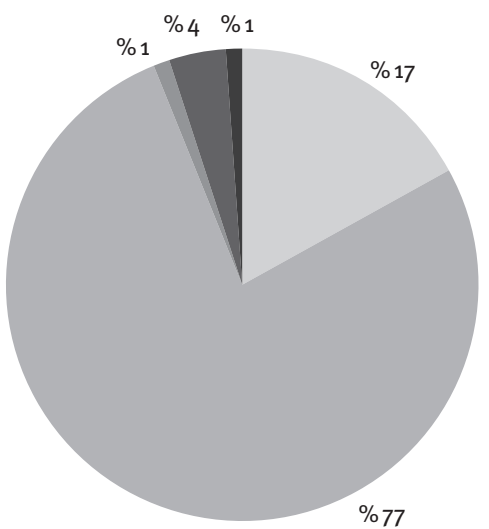

Ezkongabea

Ezkondua

Dibortzioatua

Alarguna

Besteak

Iturria: Matia Institutu Gerontologikoa.

Taldeetan parte hartzen duten pertsonen bataz besteko adina 65,03 urtekoa da, baina adin tartea oso zabala da, 37-87 urte bitartekoa. Ikasketa mailari dagokionez, lehen mailako ikasketak dituzten zaintzaileen taldea da esanguratsuena (\% 41), hala ere lanbide ikasketak (\% 24) eta bigarren mailako ikasketak (\% 16) dituztenak ere asko dira.

Ebaluatu ditugun zaintzaileetatik, erdiak baino gehiagok (\% 60) dementzia duen pertsona bat zaintzen du eta batez beste 7 urte daramatza zaintza prozesuan. Maiztasun handiago duten gaixotasunak 7. taulan agertzen dira.

7. taula. Zaindutako pertsonen gaixotasunen maiztasuna (\%)

\begin{tabular}{|l|c|}
\cline { 2 - 2 } \multicolumn{1}{l|}{} & $\%$ \\
\hline Dementzia & 60 \\
\hline Iktusa & 6 \\
\hline Narriadura kognitiboa & 6 \\
\hline Parkinson & 4 \\
\hline Gaixotasun afektiboak (depresioa, antsietatea) & 6 \\
\hline Gaixotasun kardiobaskularrak & 3 \\
\hline
\end{tabular}

Iturria: Matia Institutu Gerontologikoa.

Elkarbizitzari dagokionez, senideen gehiengoak \% 82ak mendekotasuna duen pertsonarekin bizi da etxebizitza berean eta zaintza aurrera eraman ahal izateko \% 77ak laguntzaren bat jasotzen duela 
aitortzen du. Zehazki, zaintzaileen \% 60 diru-laguntza bat jasotzen du zaintza aurrera eraman ahal izateko.

Zaintzaileei buruzko egin diren ikerketa gehienek zaintzari loturiko aspektu negatiboak azpimarratu dituzte, zaintzarekin erlazioa izan dezaketen aspektu positiboak alde batera utziz. Une berean, zaintzaile batek zaintza prozesuari lotutako aspektu positibo nahiz negatiboak bizi ditzake. Zaintzari loturiko aspektu positiboaz ari garenean, honako sentimendu hauei egiten diegu erreferentzia, besteak beste:

- Zaintzaile batzuk zainduak garai batean beregatik egin zuenagatik eskertzeko modu bat bezala ikusten dute pertsona adinduaren zaintza.

- Zaintzaile batzuk diote poztasun maila altua sentitzen dutela beste pertsona bat zaintzen egoteagatik.

- Zaintzak bere bizitzari zentzua ematen laguntzen diola.

- Zaintzak bere autoestimu maila areagotzen laguntzen diola.

Laguntza taldeetan zaintzari loturiko aspektu positibo hauek areagotzen saiatzen gara, negatiboak alde batera utzi gabe. Hori dela eta, zaintzari loturiko aspektu positiboak neurtu ditugu sei galderaz osatuta dagoen galdesorta baten bidez (Crespo eta López, 2007). Zaintzaileek bere adostasun maila adierazi behar zuten emandako esaldiekin (8. taula).

Oro har, lortutako emaitzetan ikus dezakegu zaintzaileen gehiengoak zaintzari loturiko emozio positiboak ere identifikatzen dituztela, ez bakarrik negatiboak. Halere, kontutan hartu behar da \% 10-\% 17 bitarteko zaintzailek emozio positibo hauek ikusi edo identifikatu ahal izateko zailtasunak dituela.

Kontutan hartu beharrekoa da talde hau, seguruenik zaintza soilik negatiboa izan daitekeen prozesu bat bezala bizi bait dute (ez dute alde positiborik antzematen) eta horrek zaintzari loturiko estres maila areagotu baitezake, honek zaintzailearen osasunean izan dezakeen eragin negatiboarekin.

\section{Ondorioak}

- Zaintzailearen profilari dagokionez, eredu tradizionalari jarraituz, zaintzaileen gehiengoak emakumeak dira (\% 84 bakarkako laguntza psikologikoaren kasuan eta \% 87 laguntza taldeen kasuan), 60 urte baino gehiagokoak. Gehiengoak bere ezkontidea zaintzen du, baino bada beste talde oso esanguratsua bere aita/ama edo biak zaintzen duena, adin ertaineko (bataz besteko adina 55 urteko da) alabarena, alegia.

- Sendian Programan parte hartzen duten \% 13 gizonak dira. Horren bataz besteko adina emakumeena baino altuagoa da (72,57 urte), gehienek bere ezkontidea zaintzen du (\% 69) edo bere aita/ama (31\%).

- Ikasketa mailari dagokionez, lehen mailako ikasketak dituzten edo lanbide ikasketak dituzten zaintzaileen taldeak dira esanguratsuenak. Oro har esan dezakegu aurrerapen pausu bat eman dela ikasketei dagokionez, ikasketarik gabeko zaintzaileak ia ez daudelako.

- Zainduen artean honako gaixotasun hauek dira nagusi: dementzia, iktusa, narriadura kognitiboa eta gaixotasun afektiboak (depresioa eta antsietatea), besteak beste. Senideen gehiengoak mendekotasuna duen pertsonarekin bizi dira etxebizitza berean.

- Zaintza prozesua aurrera eraman ahal izateko laguntza psikologikoaz gain (banakakoa zein taldekakoa), \% $77 \mathrm{k}$ beste motako laguntza jasotzen duela aitortzen du. Laguntza mota desberdinen artean, diru-laguntza da baliabide erabiliena.

- Zaintzari loturik emozio negatiboak zein positiboak agertzen dira, zaintzaileen gehiengoak bi motatako emozioak bizi dituzte aldi berean, baino badago talde txiki bat (\% 10-17) non bakarrik zaintzari loturiko emozio negatiboak ikusten diren. Talde hau nahiz eta txikia izan, arrisku talde bat bezala identifikatzen da, zaintzarekin loturiko emozio negatiboak besterik ez baititu bizi. Emozio negatiboen artean, antsietatea, estresa eta tristura dira sarrien

8. taula. Zaintzaren alderdi positiboak (emandako esaldiekin zaintzaileen adostasuna, \%)

\begin{tabular}{|c|c|c|c|c|c|c|c|}
\hline Esaldia & Erabat ados & Nolabait ados & Neutroa & $\begin{array}{c}\text { Erabat } \\
\text { ados ez }\end{array}$ & $\begin{array}{l}\text { Adostasun } \\
\text { eza }\end{array}$ & ED/EE & Guztira \\
\hline \multirow[t]{2}{*}{$\begin{array}{l}\text { Besteei laguntzeak poztasun maila altua } \\
\text { sortarazten dit }\end{array}$} & 54,0 & 17,0 & 16,0 & 4,3 & 5,0 & 3,7 & 100,0 \\
\hline & Beti & Oso maiz & Noizbait & Gutxitan & Inoiz & ED/EE & Guztira \\
\hline $\begin{array}{l}\text { Beste pertsona batez zaintzea beregandik } \\
\text { gertuago egotea sentiarazten nau }\end{array}$ & 46,0 & 23,0 & 24,0 & 4,0 & 1,0 & 2,0 & 100,0 \\
\hline $\begin{array}{l}\text { Zaindutako pertsonarekin nagoenean berekin } \\
\text { egoteaz gozatzen dut }\end{array}$ & 28,0 & 32,0 & 27,0 & 4,3 & 5,0 & 3,7 & 100,0 \\
\hline $\begin{array}{l}\text { Beste pertsona bat zaintzea nire autoestimu } \\
\text { maila areagotzen du }\end{array}$ & 41,0 & 16,0 & 24,0 & 11,0 & 1,4 & 6,6 & 100,0 \\
\hline $\begin{array}{l}\text { Zaintzari loturiko atseginezko egoerek } \\
\text { plazerra sortarazten naute }\end{array}$ & 70,0 & 13,0 & 11,0 & 6,0 & 0,0 & 0,0 & 100,0 \\
\hline $\begin{array}{l}\text { Beste pertsona batez zaintzeak nire bizitzari } \\
\text { zentzua ematen dio }\end{array}$ & 36,0 & 22,0 & 21,0 & 11,0 & 5,0 & 5,0 & 100,0 \\
\hline
\end{tabular}

ED/EE: ez daki / ez du erantzuten.

Iturria: Matia Institutu Gerontologikoa. 
agertzen direnak. Emozio positiboei dagokionez, berriz, zaintzari loturiko poztasun maila altua, edo zaintzaren bidez zainduarekiko gertutasun maila dira adierazleenak.

- Bakarkako saio psikologikoarekin erlazioa duen zerbitzuan, 2018 urtean 210 zaintzaile artatu ditugu, azken urteotan zerbitzu honen bidez artatu ditugun kasuen kopurua modu esanguratsu batean areagotu egin delarik.

\section{Etorkizunerako gomendioak}

Jarraian, Sendian Programaren inguruan dugun esperientzian oinarritzen diren etorkizunera begira identifikatzen ditugun hainbat erronka zehazten ditugu.

\subsection{Zaintzailearen profila}

Aurreko ataletan adierazi bezala, gaur egun oraindik ere Sendian Programaren erabiltzaile ohikoena bere senarraz zaintzen duen emakumearena da. Hau horrela izanik, azken urteotan zaintzailearen profilaren inguruan aldaketak suertatzen ari dira, hala nola gizonezkoen presentzia geroz eta handiagoa, aipatu bezala. Familien egituran azken urteotan emandako aldaketetan oinarrituz, litekeena da datozen urteotan zaintzaileen profilean oraindik aldaketa gehiago identifikatzea. Familia kideen kopuru murritza dela eta, zaintzan familia kide zuzenak ez diren pertsonen agertzea, eskura dauden baliabideen erabilera handiagoa eta baita komunitatearen geroz eta presentzia handiagoa espero daiteke. Honetaz gain, zaintzaileen profilean aniztasuna izango da nagusi. Laguntza beharrean dagoen pertsonarekiko harremana anitza izango da (senar/emaztea, seme/alaba, biloba, anai/arreba, besteak beste) eta, honi lotuta, zaintzaileen adinean ere aniztasun handia egongo dela aurreikusten da.

\subsection{Zaintza prozesua}

Azken urteotan behatu dugun beste aldaketa batek zaintza prozesuaren iraupenari egiten dio erreferentzia. Azken urteetan bizi izan ditugun aurrerapenek, bereziki medikuntza arloan, izan duten ondorioetako bat da orain zaintza prozesuak iraupen handiago dutela, zenbait kasutan hamar urte baino gehiagoko iraupena dutelarik. Zaintza prozesu luze hauek zaintzailearen ongizate fisiko eta emozionalean eragina dute. Endekapenezko gaixotasunen eboluzioa mantsoago da gainera eta ondorioz zaintza testuinguru sendo eta egonkor baten beharra dute zaintzaileek, hauen ongizatea mantentze aldera.
Pertsonen eskubide eta nahiak errespetatzea oinarri duen zaintza eredu batetan, ezin ahaz daiteke mendekotasun egoeran dauden pertsonen gehiengoaren zein zaintzaile gehienen nahia: laguntza beharrean dagoen pertsonaren zaintza bere etxean izatearena. Tradizionalki, orain arte, zaintza prozesua etxean burutu da batik bat emakumeak etxean aritzen zirelako lanean eta familiak oraingoak baina handiagoak zirelako. Gaur egun, emakumeen lan munduratzea eta familien gutxitzearekin, etxeko zaintza erronka bat bilakatu da. Aurretik aipaturiko testuinguru sendo eta egonkor hori eratzeko, zerbitzu malgu eta anitzak behar ditugu, denboran zehar pertsonen beharretara egokitzen direnak eta baita etxeko testuinguruan ematen diren behar espezifikoetarako diseinatuak izan direnak. Honetaz gain, zaintzaileen balio pertsonal, estereotipo eta sinesmenen arloan lan egin beharko litzatekeela uste dugu, oraindik ere oztopo handiak baitituzte kanpoko laguntza edo zerbitzuren bat eskatu eta onartzeko garaian. Gainera, askotan zerbitzu hauen eskaera zaintzailea egoera limite batean aurkitzen denean egiten da, maiz kalte handiak suertatu direlarik jada. Prebentzio arloan lan egitea ezinbestekoa ikusten dugu, eta honetan talde laguntzaren balioa azpimarratuko dugu. Talde hauetan zaintzari loturiko errekurtso eta baliabideen inguruko informazioa eta esperientzia pertsonalak partekatzen dira, eta zaintza prozesuan gertatu ohi diren egoerak aurreikusten laguntzen du, hauei irtenbide egokia emateko baliabide garrantzitsua direlarik. Laguntza taldeak, zaintzaileak egoera limite horretatik babesten laguntzen dutela uste dugu eta horregatik, prebentzio lana eginez, bakarkako laguntza psikologikoaren erabilera murriztuko litzatekeela uste dugu, nahiz eta kasu askotan bi baliabideen beharra ikusi.

Bukatzeko, zaintzaileen egoeraren jarraipenari erreparatuko diogu. Mendekotasun egoeran dauden pertsonen jarraipenaren inguruan ikerketa ezberdinak egin dira, eta hauetan oinarrituz, arrisku egoeran dauden pertsonen profilak identifikatu diren modu berean, arrisku egoeran dauden zaintzaileak ere identifikatzea beharrezkoa iruditzen zaigu. Honetarako, zaintzaren testuinguru aldakor honetan eta zaintzaileen profil ezberdinei erreparatuz, arrisku aldagaiak identifikatu beharko lirateke eta hauei jarraiki, zaintzaileen zaurgarritasunaren arabera hauen arriskua geruzatu, arrisku maila bakoitzerako prebentzio eta babes prozedura ezberdinak finkatuz.

\section{Eskertza}

Eskerrak emango dizkiegu Gipuzkoako Foru Aldundiko Gizarte Politiketako Departamentuko Etxean Laguntzeko Ataleko langile eta arduradunei artikulu honen garapenean erakutsitako babesarengatik. 
ARTAZA, I. eta RAMOS CORDERO, P. (zuz. zientifikoak) (2016): Estudio de investigación sociosanitaria sobre cuidadores de personas mayores dependientes, Madril, Sociedad Española de Geriatría y Gerontología.

BARRIO, E.; MAYORAL, O. eta SANCHO, M. (2015): Euskadiko 55 urteko etab gehiagoko pertsonen bizi baldintzei buruzko ikerketa, Vitoria-Gasteiz, Eusko Jaurlaritza.

BEHAGI (2018): "Demografia eta testuinguru sozioekonomikoa: biztanteria azpieskualdeka", Behagi-Gipuzkoako Gizarte Behatokia, «http://www.behagi.eus/eu/ adierazleak/biztanleria/p-2/>.

BEHAGI (2018): “Gizarte-zerbitzuetako sarea: Sendian Programa”, Behagi-Gipuzkoako Gizarte behatokia, 〈http://www.behagi.eus/eu/ adierazleak/sendian-programa/p-30/>.

BEHAGI (2018): “Premia sozialak: mendetasun-egoeraren balorazioa duten pertsonak", BehagiGipuzkoako Gizarte Behatokia, «http://www. behagi.eus/eu/adierazleak/mendetasunegoeraren-balorazioa-duten-pertsonak/p-16/>.

BOCCHI, S.C.; CANO, K.C.; BALTIERI, L.; GODOY, D.C.; SPIRI, W.C. eta JULIANI, C.M. (2010): "Moving from reclusion to partial freedom: The experience of family caregivers for disabled elderly persons assisted in a day care center", Ciência \& Saúde Coletiva, 15. lib., 6. zb., 2.973.-2.981. or.

BOERNER, K.; SCHULZ, R. eta HOROWITZ, A. (2004): "Positive aspects of caregivers experience", International Journal of Geriatric Psychiatry, 17. lib., 2. zb., 184.-188. or.

CASADO, B. eta SACCO, P. (2012): “Correlates of caregiver burden among family caregivers of older Korean Americans", The Journals of Gerontology: Series B, 67B lib., 3. zb., 331.-336. or.
CHAN, S.W. (2010): "Family caregiving in dementia: The Asian perspective of a global problem", Dementia and Geriatric Cognitive Disorders, 30. lib., 6. zb., 469.-478. or.

CRESPO, M. eta LÓPEZ, J. (2007): “Intervenciones con cuidadores de familiares mayores dependientes: una revisión", Psicothema, 19. lib., 1. zb., 72.-80. or.

DE OLIVEIRA, A.P. eta CALDANA, R.H. (2012): “As repercussões do cuidado na vida do cuidador familiar de idoso com demência de Alzheimer", Saúde e Sociedade, 21. lib., 3. zb., 675.-685. or.

EUSTAT (2019): “Euskal AEko biztanleria jaiotze urteari jarraiki, Lurralde Historiko eta sexuaren arabera”, Euskal Estatistika Erakundea, 201910-17, 〈https://eu.eustat.eus/elementos/ eleo011400/Euskal_AEko_biztanleria_jaiotze urteari_jarraiki_Lurralde_Historiko_eta_ sexuaren_arabera/tbloo11424_e.html>.

GONÇALVES, L.H.; COSTA, M.A.; MARTINS, M.M.; NASSAR, S.M. eta ZUNINO, R. (2011): "The family dynamics of elder elderly in the context of Porto, Portugal", Revista Latino-Americana de Enfermagem, 19. lib., 3. zb., 458.-466. or.

HILGEMAN, M.M.; ALLEN, R.S.; DECOSTER, J. eta BURGIO, L.D. (2007): "Positive aspects of caregiving as a moderator of treatment outcome over 12 months", Psychology and Aging, 22. lib., 2. zb., 361.-371. or.

INE (2017): “Indicadores de estructura de la población mayor de 64 años", Instituto Nacional de Estadística, 〈https://www.ine.es/jaxiT3/Tabla.htm?t=1421〉.

INE (2018): “Estadística de adquisiciones de nacionalidad por sexo y grupo de edad: resultados por comunidades autónomas", Instituto Nacional de Estadística, <https://www.ine.es/jaxiT3/ Tabla.htm?t=15082〉. 
KNIGTH, B.G. eta LOSADA, A. (2011): "Family caregiving for cognitively or psysically frail older adults: Theory, research and practice", in WARNER, K. eta WILLIS, S.L. (ed.), Handbook of the Psychology of Aging, Londres, Academic Press, 23. atala, 353.-365. or.

KUZUYA, M.; ENOKI, H. eta HASEGAWA, J. (2011): “Impact of caregiver burden on adverse health outcomes in community-dwelling dependent older care recipients", The American Journal of Geriatric Psychiatry, 19. lib., 4. zb., 382.-391. or.

NARDI, E.; DOS SANTOS, L.; DE OLIVEIRA, M. eta SAWADA, N.O. (2012): “Dificultades dos cuidadores familiares no cuidar de um idoso dependente no domicílio", Ciência, Cuidado e Saúde, 11. lib., 1. zb., 98.-105. or.

PEARLIN, L.I.; MULLAN, J.T.; SEMPLE, S.J. eta SKAFF, M.M. (1990): "Caregiving and the stress process: An overview of concepts and their measures", The Gerontologist, 30. lib., 5. zb., 583.-594. or.

PINQUART, M. eta SÖRENSEN, S. (2003): Differences between caregivers and noncaregivers in psychological health and psysical health. A meta-analysis. Psychology and Aging, 18. lib., 2. zb., 250.-267. or.

ROGERO, J. (2010): Los tiempos de cuidado. El impacto de la dependencia en la vida cotidiana de sus cuidadores, Madril, Imserso. 